\title{
Do Entrepreneurial Mindset and Perceived Behavioural Control Matter Entrepreneurial Intention?
}

\author{
Thusy Tiara Saraswati ${ }^{1}$, Aniek Indrawati ${ }^{1}$, Ludi Wishnu Wardana ${ }^{1}$ \\ ${ }^{1}$ Faculty of Economics, Universitas Negeri Malang, Indonesia
}

\begin{tabular}{l} 
Article Info \\
\hline Article history: \\
Received: 18 December 2020; \\
Accepted: 18 October 2021; \\
Published: 19 October 2021.
\end{tabular}

Keywords:

Entrepreneurial intention;

Entrepreneurial self-efficacy;

Entrepreneurial mindset;

Perceived behavioral control

\begin{abstract}
Entrepreneurial Intention is a component that can explain the mindset and have a substantial impact on individual behavior. This fact indicates how hard a person's mindset is in trying and how much effort is put in so that the desired behavior can be carried out. This study examines the direct and indirect effects of an entrepreneurial mindset, perceived behavioral control, and entrepreneurial self-efficacy on entrepreneurial intention. A total of 354 students in Malang took part in this research. We used descriptive statistical analysis, multiple linear regression analysis, and path analysis. The study results found that the entrepreneurial mindset and perceived behavioral control affected entrepreneurial self-efficacy-similarly, entrepreneurial self-efficacy, entrepreneurial mindset, and perceived behavioral control on entrepreneurial intention. Our results also found that entrepreneurial self-efficacy failed to mediate the effect of the entrepreneurial mindset on entrepreneurial intention.
\end{abstract}

\begin{abstract}
Abstrak
Entrepreneurial Intention merupakan komponen yang dapat menjelaskan pola pikir serta berdampak kuat pada tingkah laku individu. Hal ini mengindikasikan seberapa keras pola pikir seseorang dalam berusaha dan seberapa banyak usaha yang dilakukan agar perilaku yang diinginkan dapat dilakukan. Penelitian ini bertujuan untuk menguji pengaruh langsung dan tidak langsung entrepreneurial mindset, perceived behavioral control, dan entrepreneurial self-efficacy terhadap entrepreneurial intention. Sebanyak 354 mahasiswa di Kota Malang ambil bagian dalam penelitian ini. Kami menggunakan analisis statistik deksiptif, analisis regresi linier berganda dan analisis jalur. Hasil penelitian menemukan bahwa entrepreneurial mindset dan perceived behavioral control berpengaruh terhadap entrepreneurial selfefficacy. Demikian pula entrepreneurial self-efficacy, entrepreneurial mindset, dan perceived behavioral control terhadap entrepreneurial intention. Hasil penelitian kami juga menemukan bahwa entrepreneurial self-efficacy gagal memediasi pengaruh entrepreneurial mindset terhadap entrepreneurial intention.
\end{abstract}

\section{How to Cite:}

Saraswati, T. T., Indrawati, A., \& Wardana, L. W. (2021). Do Entrepreneurial Mindset and Perceived Behavioural Control Matter Entrepreneurial Intention?.Jurnal Pendidikan Ekonomi \& Bisnis, 9(2), 131-145. https://doi.org/10.21009/JPEB.009.2.5

* Corresponding Author.

thusy.tiara.1904157@students.um.ac.id. Thusy Tiara Saraswati 


\section{INTRODUCTION}

Unemployment and employment problems are still a significant concern in every country globally, especially in developing countries. These two problems are interrelated (Muhson, et al., 2012; Soleh, 2017). The Open Unemployment Rate (TPT), based on official data from the Central Statistics Agency (BPS), increased to 6.88 million people as of February 2020. This number has increased by $4.99 \%$ from last year. BPS also released the number of jobs that experienced an increase only in education services ( 0.24 percentage points), construction ( 0.19 percentage points), and health services (0.13 percentage points) (bps.go.id). Compared with the total population in Indonesia as of June 30, 2020, which reached 268.6 million (dukcapil.kemendagri.go.id). Of course, the inadequate job creation with the current population growth has resulted in many unemployed people (Buhaug \& Urdal, 2013; Majale, 2008). The increase in the number of unemployed will cause many other related problems and the level of welfare and poverty (Busemeyer, 2019; Hines, et al., 2004).

Indonesia and countries worldwide are experiencing a severe problem, namely the 2019 coronavirus pandemic (Covid-19). The first time this virus was detected was in Wuhan, China, in December 2019. This outbreak has been growing very fast. WHO then labeled the coronavirus outbreak as a global pandemic (WHO, 2020). The Indonesian government launched a health protocol through a task force to accelerate the handling of Covid-19. Hidayat (2020) stated that this health protocol was carried out to suppress the spread of the virus while at the same time balancing socioeconomic activities that had been halted due to this pandemic. The Covid-19 task force divides the provisions of community activities based on the color of the zones in the area. The color of this zone is determined by how many patients are infected with the virus and how fast the patients are growing (Telaumbanua, 2020). The impact is the weakening of the world economy in terms of trade, investment, and tourism (Pakpahan, 2020). With the applicable activity restrictions, in the end, many companies choose to terminate some of their employees to offset production costs with sales proceeds (Syawfi, 2020).

As a result, unemployment has increased even more. Minister of National Development Planning / Bappenas, Suharsono, in a working meeting with Commission XI DPR RI on June 22, 2020, said that workers in the manufacturing industry numbered 18 million people and, due to this pandemic, experienced layoffs of 9.8 million people due to low manufacturing utilization (dpr.go.id). Djausal et al. (2020) explained that the low availability of job opportunities would undoubtedly make it challenging to get a new job. Many people end up looking for a way out to survive and make a living. The work that can still do is only certain activities that can pair with a pandemic. One type of work that can survive until now is entrepreneurship (Pakpahan, 2020).

Haynie, et al., (2010) dan Schaefer \& Minello (2019) The entrepreneurial mindset needs to be owned by an entrepreneur, where entrepreneurs must have characters, including simple thinking, oriented to new things, action-oriented, able to read, and take opportunities. An entrepreneur will be encouraged to continue making innovations to create profitable opportunities (Suaidy \& Lewenussa, 2019). This entrepreneurial mindset needs to be instilled from the start to plan and pattern the entrepreneurial strategies. Besides, entrepreneurial behavior is also required to start realizing the desire to become an entrepreneur. Pfeifer et al. (2016) found an influence of entrepreneurial mindset on entrepreneurial intentions in business program students in Croatia. Borchers \& Park (2010) found an influence of an entrepreneurial mindset on the intention to start a business.

Apart from the entrepreneurial mindset needed to support the intention, entrepreneurial behavior must also prepare. Perceived Behavioral Control (PBC) this theory comes from the view of planned behavior (Ajzen, 2002). It is assume that most human social behavior is under the control of the will and, therefore, can be predicted from an intention. Establishing perceived behavioral control is added to deal with situations in which people may lack complete will control over the behavior of interest (Ishoy, 2016). Even perceived behavior tends to influence intentions (Hanson, et al., 2015). A high level of perceived behavioral control strengthens a person's intention to perform a behavior and increases effort and persistence. In this mode, perceived behavioral control can influence behavior indirectly, with its impact on individual intentions (Ru et al., 2018). Tuu (2015) 
The research results found an influence between perceived behavioral control and consumers' intention in a coastal province in Central Vietnam. Cera \& Furxhiu (2017) The study results found a statistically significant influence of $\mathrm{PBC}$ on entrepreneurial intention.

Business actors must have a level of self-confidence and must believe in their abilities to make every decision and minimize risks that may be accepted (Oyugi, 2015). The belief in entrepreneurship is base on the social cognitive aspects through an approach between individuals and the environment (Drnovšek, et al., 2010). Miao et al. (2017) explained that individuals who have higher self-confidence from the beginning of career development would have higher entrepreneurial intentions, and those who have increased self-confidence and purposes will have more opportunities to engage in entrepreneurial activities. However, a business actor who has low self-efficacy will tend to fail (Nowiński, et al., 2019). Entrepreneurial self-efficacy is supported by research results Murugesan \& Jayavelu (2017), who found an effect of self-efficacy on entrepreneurial intention. Travis \& Freeman (2017) found that entrepreneurial self-efficacy influences entrepreneurial intention.

Higher education is an educational institution responsible for producing graduates who can immediately work (Hermawan, 2019). The concept of working here is working with other people to become employees or work for themselves to become entrepreneurs. Fikri, et al., (2016). Higher education institutions also provide facilities that support students to become entrepreneurs. Among them, they provide student cooperatives as a place for their direct practice to start selling products. The existence of entrepreneurship education is intended to broaden students' insight into the world of entrepreneurship. A prepared curriculum supports the refinement of this entrepreneurial education model (Wardana et al., 2020). Student activity unit that encourages students to develop an entrepreneurial spirit motivates them to be directly involved in the world of entrepreneurship (Novita, 2015; Robert W. Fairlie, 2020).

As an education city, Malang has many learning facilities, one of which is a university (Sari, 2012). The number of universities in Malang reaches 58 campuses. In connection with this, Malang is visite by many students from all over Indonesia who want to get an education. As education providers, tertiary institutions must deliver students to complete their studies equipped with adequate knowledge and skills to enter the community later. One can produce graduates who can create new jobs by opening a business or entrepreneurship (Pujiastuti et al., 2015). Besides, with the current situation in a pandemic, students as a new spirit are expected to become healthy young entrepreneurs. Of course, they can contribute to improving the economy and reduce the unemployment rate in Indonesia.

The contribution of this research includes adding insight into entrepreneurial intention, entrepreneurial mindset, perceived behavioral control, and entrepreneurial self-efficacy in students to support previous research (Aima, 2020; Ashourizadeh et al., 2014; Borchers \& Park, 2010; Burnette et al., 2019; Jabeen et al., 2017; Pfeifer et al., 2016; Pihie \& Arivayagan, 2016; Song, C. W., \& Park, 2020). This study also investigates entrepreneurial behavior and entrepreneurial mindset with the hope that students who have entrepreneurial intentions can become entrepreneurs, open new jobs, and assist the government in unemployment and poverty alleviation programs.

\section{METHOD}

This study used a quantitative approach. This type of research is descriptive explanatory because it intends to find the influence between variables (Hair, 2006). Descriptive is used in interpreting, analyzing and presenting data from research variables. The explanation is used to explain the causal effect between variables through hypothesis testing (Hasan, 2009). The independent variables in this study are the entrepreneurial mindset $\left(\mathrm{X}_{1}\right)$, perceived behavioral control $\left(\mathrm{X}_{2}\right)$, the intervening entrepreneurial self-efficacy variable $(\mathrm{Z})$, and the dependent variable entrepreneurial intention $(\mathrm{Y})$. This research instrument is a questionnaire resulting from the adoption of previous research on entrepreneurial mindset (Mathisen \& Arnulf, 2013), perceived behavioral control (Liñán \& Chen, 2009), entrepreneurial self-efficacy (Zhao et al., 2005), and 
entrepreneurial intention (Krueger et al., 2000; Liñán \& Chen, 2009).

The population in this study were students of the undergraduate study program in Business and Management of State Universities in Malang, East Java, comprise Universitas Negeri Malang (UM), Universitas Brawijaya (UB), and Universitas Islam Negeri Maulana Malik Ibrahim (UIN Maliki). The study programs include S1 Management, S1 Business Education, S1 Entrepreneurship, S1 Business Administration Science, and S1 Islamic Business Law, with a population of 3120 students. The sample was calculated size in this study using the Slovin formula with the results of the calculation of 354 respondents. The sampling technique in this study is probability sampling. The type used in this research is proportional random sampling, where the sample in this study is taken proportionally with random sampling to determine the selection of each study program. The data analysis technique used descriptive statistical analysis, multiple linear regression, and path analysis. Hypothesis testing uses the t-test to determine the direct effect and the Sobel test to determine the indirect effect.

\section{RESULTS AND DISCUSSION}

Based on the results of the descriptive statistical analysis of respondents, that the respondents answered the questionnaire were 354 respondents (See table 1)

Table 1. Demographic of Respondent

\begin{tabular}{lcc}
\hline \multicolumn{1}{c}{ Characteristic } & Frequency & Percentage \\
\hline $\begin{array}{l}\text { 1. Gender } \\
\text { Female }\end{array}$ & 196 & 55.4 \\
2. College & 158 & 44.6 \\
$\quad \begin{array}{l}\text { Universitas Brawijaya } \\
\text { 3ubject }\end{array}$ & 198 & 55.9 \\
$\begin{array}{l}\text { S1 Management } \\
\text { 4. Parents Occupation } \\
\text { Entrepreneur }\end{array}$ & 285 & 80.5 \\
\hline
\end{tabular}

Path analysis in this study was used to determine the direct and indirect effect on the dependent variable. The path analysis coefficient in this study consists of two regression equations, namely, the first equation, regression from variable $X_{1}$ to variable $Z$ and from variable $X_{2}$ to variable $Z$. The equation formula is $Z=\rho_{\mathrm{zx}_{1}} \mathrm{X}_{1}+\rho_{\mathrm{zx}_{2}} \mathrm{X}_{2}+\rho_{\mathrm{z}_{1}}$. In the second equation, the regression of the variables $X_{1}$ to variable $Y$, from variable $X_{2}$ to variable $Y$ and from variable $Z$ to variable $Y$. The equation formula is $\mathrm{Y}=\rho_{\mathrm{yx}_{1}} \mathrm{X}_{1}+\rho_{\mathrm{yx}_{2}} \mathrm{X}_{2}+\rho_{\mathrm{yz}} \mathrm{Z}+\rho_{\mathrm{y} \varepsilon_{2}}$. The combination of the results of the partial analysis of the two regression equations is described as follows.

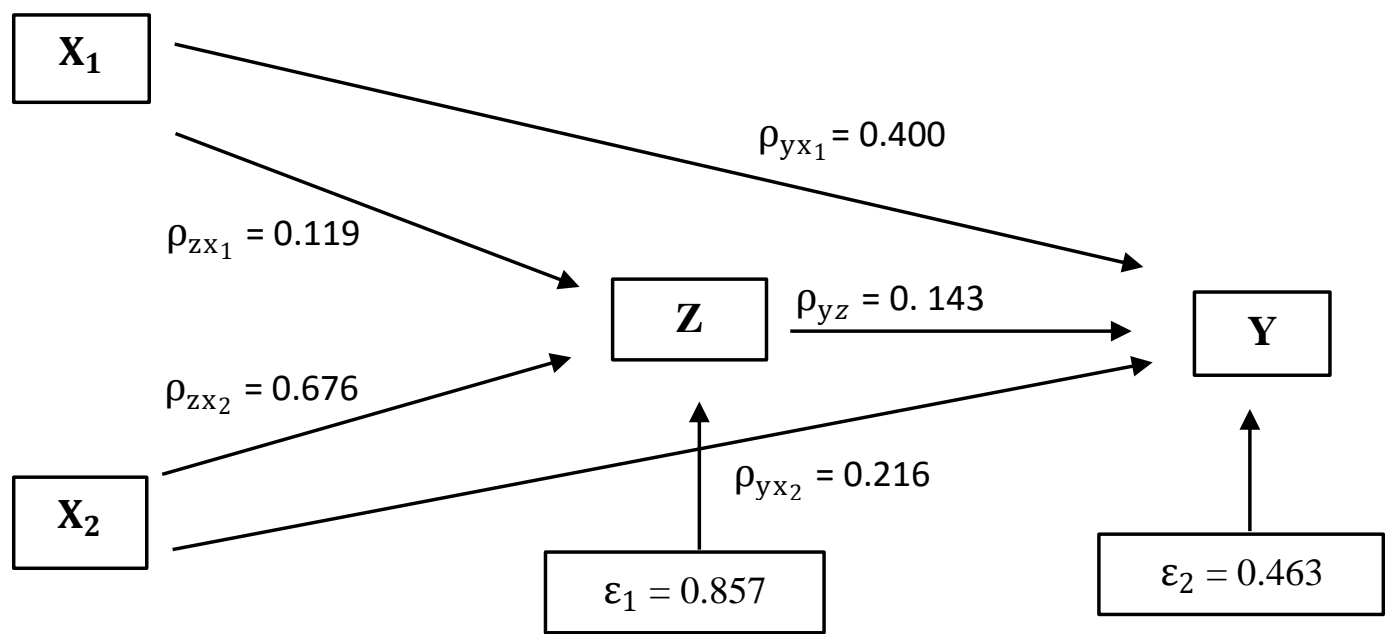

Figure 1. Structural Equation Model 
Based on the linear regression output in the first equation, it is known that the significance value of the entrepreneurial mindset $\left(\mathrm{X}_{1}\right)$ is 0.003 less than $0.05(\mathrm{sig} \leq 0.05)$ and shows the value of $\mathrm{t}_{\text {count }} 2.953>\mathrm{t}_{\text {table }}$ 1.653. Perceived behavioral control $\left(\mathrm{X}_{2}\right)$ is 0,000 less than $0.05(\mathrm{sig} \leq 0.05)$ and shows the value of $t_{\text {count }} 16.852>t_{\text {table }} 1.653$. This result shows that the regression in the first equation, $X_{1}$ and $X_{2}$ has a significant effect on $Z$. Effect of errors $\rho_{z_{1}}=0,841$.

Based on the linear regression output in the second equation, it is known that the significance value of the entrepreneurial mindset $\left(\mathrm{X}_{1}\right)$ is 0.000 less than $0.05(\mathrm{sig} \leq 0.05)$ and shows the value of $\mathrm{t}_{\text {count }} 8.556>\mathrm{t}_{\text {table }}$ 1.653. Perceived behavioral control $\left(\mathrm{X}_{2}\right)$ is 0.001 less than $0.05(\mathrm{sig} \leq 0.05)$ and shows the value of $t_{\text {count }} 3.472>t_{\text {table }}$ 1.653. Entrepreneurial self-efficacy (Z) is 0.020 less than 0.05 $(\operatorname{sig} \leq 0.05)$ and shows the value of $t_{\text {count }} 2.332>t_{\text {table }} 1.653$. This result shows that the regression in the second equation, $\mathrm{X}_{1}, \mathrm{X}_{2}$ and $\mathrm{Z}$ has a significant effect on $\mathrm{Y}$. Effect of $\rho_{\mathrm{y} \varepsilon_{2}}=0.919$.

Based on the results of the Sobel test calculation, the effect of entrepreneurial self-efficacy on entrepreneurial intention through entrepreneurial self-efficacy shows the value of $t_{\text {count }} 1.829<$ $t_{\text {table }}$ 1.967. So, it can conclude that in this study, the entrepreneurial mindset variable has no indirect effect on entrepreneurial intention through entrepreneurial self-efficacy, and the entrepreneurial self-efficacy variable is not able to mediate entrepreneurial mindset on entrepreneurial intention. The effect of perceived behavioral control through entrepreneurial selfefficacy on entrepreneurial intention shows the value of $t_{\text {count }} 2.302<t_{\text {table }}$ 1.967. So, it can conclude that in this study, the variable perceived behavioral control has an indirect influence on entrepreneurial intention through intervening entrepreneurial self-efficacy, and the entrepreneurial self-efficacy variable can mediate perceived behavioral control on entrepreneurial intention.

Based on the results of the analysis of the direct effect of the entrepreneurial mindset (EM) on entrepreneurial self-efficacy (ESE), hypothesis testing has met the predetermined criteria. This means that there is a direct influence between EM and ESE. The results of this study are in line with previous research conducted by Pihie \& Arivayagan (2016), Wardana et al. (2020), and Burnette et al. (2019).

Pihie \& Arivayagan (2016) explained that the result of the study is a significant positive relationship between entrepreneurial mindset and self-confidence related to entrepreneurial competence. Because self-competence is determined by goal orientation, achievement, and a focus on proactivity and creativity, because the entrepreneurial mindset focuses on innovation and risktaking, it cannot immediately ignore self-competence skills. Students are more oriented towards a higher entrepreneurial mindset when they perceive a risk tendency. Meanwhile, the tendency to risk is very much determined by individual character.

Burnette et al. (2019) explained the research results on the growth of the entrepreneurial mindset suitable for increasing self-confidence in entrepreneurship. Growing an entrepreneurial mindset can be interpreted as a challenge that adds to the lack of experience and strengthens the self-confidence to develop in entrepreneurship. Someone with a vital entrepreneurial mindset is willing to overcome all the risks of his business, while people with a weak mindset tend to be silent and cannot do more. The results showed that their subjects had a healthy entrepreneurial mindset with self-confidence in having competence in achieving success. A healthy mindset can encourage one to solve existing problems and challenges, rise from failures, and innovate. An entrepreneuroriented person prefers to live with uncertainty rather than avoid and sees things more positively than others who see them as complex, willing to learn something from taking risks (Lindberg et al., 2017). The mindset of an entrepreneur is rooted in persistence, persistence, and never give up (Pfeifer et al., 2016).

Although EM and ESE for students of the business education undergraduate study program in Malang, this study has good scores. However, there are still answers to their disapproval of entrepreneurship. Students to be challenging to develop because of the many considerations to become entrepreneurs. Students consider the positive and negative aspects of getting into entrepreneurship, the availability of time, financial ability, and the seriousness of the intention to 
become an entrepreneur (Mathisen \& Arnulf, 1970). Students have many opportunities and time to learn many things outside of their studies when viewed from the activities. So that the chance to become a prominent entrepreneur for him.

Based on the results of the analysis of the direct effect of perceived behavioral control (PBC) on entrepreneurial self-efficacy (ESE), the hypothesis testing has met the predetermined criteria. That is, there is a direct influence between the PBC and the ESE. The results of this study are in line with previous research conducted by Do \& Dung (2020), Doanh \& Bernat (2019), Kim et al. (2020), and Tsai et al. (2016).

Perceived behavioral control is a belief about the presence or absence of factors that facilitate and prevent individuals from carrying out a behavior (Chen, 2016). A person's behavior is not only controlled by himself but also requires control, for example, in the form of self-control over something that is expected (Piperopoulos \& Dimov, 2015). Individuals who have a high perception of control will continue to be motivated and strive to succeed because they believe that somebody can overcome the difficulties they face with the available resources and opportunities. Ajzen (2015) menyampaikan bahwa pengendalian perilaku ini, bersama-sama dengan niat berinteraksi dengan melakukan atau tidak melakukan suatu perilaku.

In addition to control perceptions, the construction of entrepreneurial self-efficacy also plays a role in determining and explaining entrepreneurial actions (Shinnar et al., 2014). The construction of self-efficacy is an individual's perception of his ability to carry out the necessary actions to face prospective situations. Self-efficacy includes internal control factors such as knowledge and skills and reflects a person's perception of the ease or difficulty of performing specific behaviors and confidence in their ability to perform these behaviors. Therefore, understanding entrepreneurial self-efficacy is very important because it explains the behavior of those who are willing to become entrepreneurs and those who are already entrepreneurs (Yusof et al., 2018).In this study, PBC and ESE for students of the business education undergraduate study program in Malang have good scores. Some students in Malang still have difficulties in maintaining the businesses they have built (Liñán \& Chen, 2009). However, they are ready to start a viable business and identify new business opportunities (Zhao et al., 2005). With a strong belief in behavioral control and self-confidence, students in Malang will likely succeed in running a business.

Based on the analysis results of the direct influence of entrepreneurial self-efficacy (ESE) on entrepreneurial Intention (EI), the hypothesis testing has met the predetermined criteria. That is, there is a direct influence between ESE and EI. The results of this study are in line with previous research conducted by Asimakopoulos et al. (2019), Fragoso et al. (2019), Hsu et al. (2019), Neneh (2020), Osiri et al. (2019), and Vamvaka et al., 2020). The intention is the seriousness of someone's choice to do an action or bring up a particular behavior (Kim et al., 2020). Entrepreneurial intention is related to the ability to dare to meet the needs of life and solve life problems, promote business or create new companies with the strength in oneself (Shinnar et al., 2014). Entrepreneurial intention is a psychological symptom to focus attention and do something about the entrepreneur with a happy feeling because it benefits him (Mathieu, 2015). Gachanja (2016) defines entrepreneurial selfefficacy as the belief that individuals have their own ability to build new businesses successfully. Pollack et al. (2012) entrepreneur self-efficacy is considered necessary in starting and developing new businesses. These behaviors and beliefs are considered significant factors are contributing to entrepreneurial success during the early stages of starting a company (Naktiyok et al., 2010).

Starting a new business is an intentional act (Ana et al., 2016). Primarily because of factors from within the individual and the environment. In the case of entrepreneurship, entrepreneurial self-efficacy can consist of considering tasks related to the intention and development of new businesses (Travis \& Freeman, 2017). Entrepreneurial self-efficacy refers to belief in a person's ability to perform entrepreneurial tasks and activities (Rankhumise, 2014). It is means entrepreneurial self-efficacy is very important because the entrepreneurial intention is part of the entrepreneurial aspect in influencing career choices (Nowiński \& Haddoud, 2019). In this study, ESE and EI for students of the business education undergraduate study program in Malang have good scores. Students in Malang can make new products and think creatively (Zhao et al., 2005) to maximize the intention and determination to become an entrepreneur (Krueger et al., 2000). 
Based on the results of the analysis of the direct effect of the entrepreneurial mindset (EM) on entrepreneurial Intention (EI), hypothesis testing has met the predetermined criteria. This means that there is a direct influence between the EM variable and the EI variable. The results of this study are in line with previous research conducted by Jabeen et al. (2017), Handayati et al. (2020), and Song \& Park (2020).

According to Commarmond (2017), mindset means that a person must be free to think and open his mind to limit himself to new things and new knowledge by following visionary and optimistic concepts. A sign that someone is in the process of building a new paradigm to find inspiration by using a creative mindset (Rajh et al., 2017). McMullen \& Kier (2016), many things are created twice. The first creation begins with the mind and the second creation is the realization of what is in the mind. One of the determinants of a person's quality of life is the mind. Therefore, to create a quality life and expectations, the first step starts from the mindset. The entrepreneurialoriented frame of mind prefers to live with uncertainty rather than avoid, sees things more positively than others who see them as complex, willing to learn something that comes from taking risks accompanied by realized intentions (Bosman \& Fernhaber, 2017).

Somebody can say that entrepreneurial intention is the tendency of individuals to take entrepreneurial actions by creating new products through business opportunities and taking risks (Ridley et al., 2017). Therefore, the intention can use as a necessary, sensible approach to understanding which will become entrepreneurs (Daniel, 2016). Thus, company creation results from planned behavior, and it is best predicted by the intentions present in the individual.

An individual with a positive mindset will be more able to develop inner abilities, think broadly and deeply, and do all activities. This way of thinking and attitude is very conducive to creativity, innovation, and it is easier to build enthusiasm and persistence in running a business (Scheepers, 2008). The world is full of risks, so an entrepreneur with a negative mindset cannot read opportunities and take risks. In this study, EM and EI for students of Business education study program students in Malang have good scores. They consider their seriousness to be an entrepreneur (Mathisen \& Arnulf, 2013). They also do their best to start and run the business they have built because the main goal is to become an entrepreneur (Krueger et al., 2000).

Based on the results of the analysis of the direct effect of perceived behavioral control (PBC) on entrepreneurial Intention (EI), the hypothesis testing has met the predetermined criteria. This means that there is a direct influence between PBC and EI. The results of this study are in line with previous research conducted by Anggadwita \& Dhewanto (2015), Apasieva (2020), Cera \& Furxhiu (2017), Handayani \& Prajogo (2020), Sahinidis et al. (2019), and Shabbir (2016).

In general, entrepreneurs will use their ingenuity to take advantage of various available and limited resources. This shows the importance of entrepreneurial intention because this intention will play a crucial role in making a person's decision to establish a new business or company. This intention is based on how individuals perceive themselves, social desires for their behavior, and individual perceptions of their ability to succeed (Rajh et al., 2017). Individuals need to be committed to starting a new business and need to pay attention to understanding the process of creating a new business (Ambad \& Damit, 2016).

Meanwhile, perceived behavioral control represents a person's belief about how easily individuals show a behavior (Karimi et al., 2016). When an individual believes that he lacks resources or does not have the opportunity to demonstrate a behavior (low behavioral control), the individual will not intend to show that behavior (Yang, 2013). Ajzen (2005), there are two important things related to the planned behavior theory. The first is the assumption that PBC has motivational implications for intentions. Someone who believes that he does not have the resources or does not have the opportunity to bring out the behavior is more likely not to have a firm intention to bring out the behavior. According to Fishbein \& Ajzen (1975), the intention is a component in an individual that refers to the desire to perform a particular behavior. The intention is defined as an individual's subjective probability dimension in the relation between self and behavior. Based on the description above, somebody can state that intention is the seriousness of a person's choice to take action or bring up a particular behavior. In this study, PBC and EI for students of the business education undergraduate study program in Malang have good scores. Students are more likely to be successful 
in running a business if they can control the process of creating a new business because they are ready to do anything to become entrepreneurs (Liñán \& Chen, 2009).

Based on the analysis, the entrepreneurial mindset variable does not have an indirect effect on entrepreneurial intention through entrepreneurial self-efficacy, and the entrepreneurial selfefficacy variable cannot mediate the entrepreneurial mindset on entrepreneurial intention. The results of this study are not in line with previous research conducted by Aima (2020) and Ashourizadeh et al. (2014). Aima (2020), in his research, found that to increase entrepreneurial intention by increasing the mindset about entrepreneurship. Therefore, anyone who wants to become an entrepreneur must prepare himself by observing and experiencing everything related to entrepreneurial activities. Business looks the easiest to understand. Its differentiation into entrepreneurship determines by how to think and act. This aspect of an entrepreneur refers to a mindset. With a willingness to accept different challenges, a foundation for entrepreneurial education forms.

Ashourizadeh et al. (2014), In their research, suggests that the results show that people who believe more in innovation will more often intend to start an entrepreneurial business. Some people can consider this belief in innovation part of an entrepreneurial mindset because confidence in innovation is higher for entrepreneurs than non-entrepreneurs. Belief in innovation is positively related to other components of an entrepreneurial mindset, particularly self-efficacy, opportunity awareness, risk propensity, and role modeling. It is hoped that this can affect people's intention to start a business. Entrepreneurial intention is the first and most crucial step for an entrepreneur.

In this study, although EM, ESE, and EI have good scores. The results of ESE mediation on EM against EI do not affect. When viewed from the respondents' characteristics, students still consider that being an entrepreneur is the right step. Sometimes they feel it is the wrong step. They are also still looking for advantages and disadvantages in entrepreneurship. Even though they already have a business idea that they can implement (Mathisen \& Arnulf, 2013). In this regard, somebody can conclude that this student has some serious doubts about starting a business (Liñan \& Chen, 2009; Krueger et al., 2000).

A person should have an entrepreneurial mindset to be described with the following characteristics: lifelong learning and openness to change. Second, engagement in a complex and uncertain world. Third, creative and innovative approaches to problem-solving. Fourth, confidence and belief in one's capacity and competence to be entrepreneurial. Fifth, desire, motivation, and intention to practice entrepreneurship and behave entrepreneurially. Sixth, take the initiative and personal responsibility in acting. Seventh, the pursuit of goal achievement through personal mastery and value creation. Eighth, recognizing opportunities. Ninth, patience and persistence in facing challenges. Tenth, taking risks that lead to learning and growth. Eleventh, a belief in one's ability to influence.

Based on the analysis results, perceived behavioral control indirectly affects entrepreneurial intention through intervening entrepreneurial self-efficacy, and the entrepreneurial self-efficacy variable can mediate perceived behavioral control on entrepreneurial intention. The results of this study are in line with previous research conducted by Ok (2020) and Shi et al. (2020). In their research, Shi et al. (2020) believe that the current context of transformation and improvement of China's economy can achieve from the increase in mass entrepreneurship and innovation promoted by students; efforts to increase this have begun from the following aspects. First, universities can continue to improve the quality of entrepreneurship education. Somebody can do this by developing entrepreneurship module teaching materials to foster student creativity and refining entrepreneurial education learning methods to increase student understanding of entrepreneurship and stimulate student creativity. Second, the government can create a better entrepreneurial environment for entrepreneurial students in universities. Somebody can provide preferential policies for students, such as setting up a special entrepreneurship support fund, providing free business premises, and providing tutorials. In this study, students in Malang are ready to start a viable business because they know how to develop their business, can learn the most crucial part of starting a business (Liñán \& Chen, 2009), and able to commercialize an idea or product development (Zhao et al., 2005). 


\section{CONCLUSIONS AND SUGGESTION}

This study aims to determine the entrepreneurial intentions of students in Malang. The analysis results directly affect the entrepreneurial mindset and perceived behavioral control on entrepreneurial self-efficacy: entrepreneurial self-efficacy, entrepreneurial mindset, and perceived behavioral control on entrepreneurial intention. Based on the Sobel test results, the entrepreneurial mindset variable has no indirect effect on entrepreneurial intention through entrepreneurial self-efficacy, and perceived behavioral control indirectly influences entrepreneurial intention through intervening entrepreneurial self-efficacy. Students in Malang with different characteristics, after testing, are ready to start entrepreneurship.

The limitation of this research is that the researcher has not been able to explain the factors that influence entrepreneurial intention widely and the research subject only focuses on students from the business and management study program. The excellent acquisition of all variables evidences this. It is hoped that universities will continue to carry out activities that support students in entrepreneurship. For future researchers, it is hoped that this study's results can be used as a source of reference and further research on entrepreneurial intention.

\section{REFERENCES}

Aima. (2020). Effect of Global Mindset and Entrepreneurial Motivation to Entrepreneurial SelfEfficacy and Implication to Entrepreneurial Intention. Dinasti International Journal of Digital Business Management, 1(2), 1-16. https://doi.org/10.31933/DIJDBM

Ajzen, I. (2002). Ajzen I. Perceived Behavioral Control, Self- Efficacy, Locus of Control, and the Theory of Planned Behavior1. Journal of applied social psychology. 2002;32(4):665-83. No Title. Journal of Applied Social Psychology., 32(4), 665-683.

Ajzen, Icek. (2015). Consumer attitudes and behavior: the theory of planned behavior applied to food consumption decisions. Consumer Attitudes and Behavior: The Theory of Planned Behavior Applied to Food Consumption Decisions, 70(2), 121-138. https://doi.org/10.13128/REA-18003

Ambad, S. N. A., \& Damit, D. H. D. A. (2016). Determinants of Entrepreneurial Intention Among Undergraduate Students in Malaysia. Procedia Economics and Finance, 37(16), 108-114. https://doi.org/10.1016/s2212-5671(16)30100-9

Ana, A., Hurriyati, R., Rostika, Y., \& Nazeri, M. (2016). Entrepreneurial intentions of tourism vocational high school students in Indonesia and Malaysia. Journal of Technical Education and Training, 8(2), 12-20.

Anggadwita, G., \& Dhewanto, W. (2015). Women's Entrepreneurial intentions in micro and small enterprises (MSEs) in Indonesia: The influence of environmental factors on perceived behavioral control. Journal of Administrative and Business Studies, 1(1), 1-7. https://doi.org/10.20474/jabs-1.1.1

Apasieva, T. J. (2020). Theory of Planned Behavior: Personal Attitude and Perceived Behavioral Control as Key Determinants in Creation of Entrepreneurial Societies and Social Inclusion of Young People. Balkan Social Science Review, 15, 275-297.

Ashourizadeh, S., Chavoushi, Z. H., \& Schøtt, T. (2014). People's confidence in innovation: A component of the entrepreneurial mindset, embedded in gender and culture, affecting entrepreneurial intention. International Journal of Entrepreneurship and Small Business, 23(1-2), 235-251. https://doi.org/10.1504/IJESB.2014.065310

Asimakopoulos, G., Hernández, V., \& Miguel, J. P. (2019). Entrepreneurial intention of engineering students: The role of social norms and entrepreneurial self-efficacy. Sustainability 
(Switzerland), 11(16), 1-17. https://doi.org/10.3390/su11164314

Bae, T. J., Qian, S., Miao, C., \& Fiet, J. O. (2014). The Relationship Between Entrepreneurship Education and Entrepreneurial Intentions: A Meta-Analytic Review. Entrepreneurship: Theory and Practice, 38(2), 217-254. https://doi.org/10.1111/etap.12095

Borchers, A., \& Park, S. (2010). Understanding Entrepreneurial Mindset: a Study of Entrepreneurial Self-Efficacy, Locus of Control and Intent To Start a Business. The Journal of Engineering Entrepreneurship, 1(1), 51-62.

Bosman, L., \& Fernhaber, S. (2017). Teaching the entrepreneurial mindset to engineers. Teaching the Entrepreneurial Mindset to Engineers, 2012, 1-142. https://doi.org/10.1007/978-3-31961412-0

Buhaug, H., \& Urdal, H. (2013). An urbanization bomb? Population growth and social disorder in cities. Global Environmental Change, 23(1), https://doi.org/10.1016/j.gloenvcha.2012.10.016

Burnette, J. L., Pollack, J. M., Forsyth, R. B., Hoyt, C. L., Babij, A. D., Thomas, F. N., \& Coy, A. E. (2019). A Growth Mindset Intervention: Enhancing Students' Entrepreneurial Self-Efficacy and Career Development. Entrepreneurship: Theory and Practice, 1(31). https://doi.org/10.1177/1042258719864293

Busemeyer, M. R. (2019). The welfare state with private alternatives : The transformation of popular support for social insurance. The Journal of Politics, 82(2), 1-35. https://doi.org/10.1086/706980

Cardon, M. S., \& Kirk, C. P. (2015). Entrepreneurial Passion as Mediator of the Self-Efficacy to Persistence Relationship. Entrepreneurship: Theory and Practice, 39(5), 1027-1050. https://doi.org/10.1111/etap.12089

Cera, E., \& Furxhiu, N. (2017). Factors which Influence Students Enterpreneurship Intentions: The Role of Education Programs, Subjective Norms and Perceived Behavioral Control. Journal of Educational and Social Research, 7(1), 173-179. https://doi.org/10.5901/jesr.2017.v7n1p173

Chen, M. F. (2016). Extending the theory of planned behavior model to explain people's energy savings and carbon reduction behavioral intentions to mitigate climate change in Taiwanmoral obligation matters. Journal of Cleaner Production, 112, 1746-1753. https://doi.org/10.1016/j.jclepro.2015.07.043

Commarmond, I. (2017). In Pursuit of a Better Understanding of and Measure for Entrepreneurial Mindset Contents. September, 34. www.allangrayorbis.org

Daniel, A. D. (2016). Fostering an entrepreneurial mindset by using a design thinking approach in entrepreneurship education. Industry and Higher Education, 30(3), 215-223. https://doi.org/10.1177/0950422216653195

Davis, M. H., Hall, J. A., \& Mayer, P. S. (2015). Developing a new measure of entrepreneurial mindset: Reliability, validity, and implications for practitioners. Consulting Psychology Journal: Practice and Research, 67(4), 1-28. https://doi.org/10.1037/cpb0000045

Djausal, G. P., Larasati, A., Ilmu, J., Bisnis, A., Lampung, U., \& Alam, Y. S. (2020). Strategi pariwisata ekologis dalam tantangan masa pandemi Covid-19. 3, 57-61.

Do, Q. H., \& Dung, P. Q. (2020). Exploring entrepreneurial intention of full-time students at transport universities in Vietnam. Management Science Letters, 10, 1409-1416. https://doi.org/10.5267/j.msl.2019.12.027

Doanh, D. C., \& Bernat, T. (2019). Entrepreneurial self-efficacy and intention among Vietnamese students: A meta-analytic path analysis based on the theory of planned behavior. Procedia Computer Science, 159, 2447-2460. https://doi.org/10.1016/j.procs.2019.09.420

Drnovšek, M., Wincent, J., \& Cardon, M. S. (2010). Entrepreneurial self-efficacy and business start- 
up: Developing a multi-dimensional definition. International Journal of Entrepreneurial Behaviour and Research, 16(4), 329-348. https://doi.org/10.1108/13552551011054516

Espíritu-Olmos, R., \& Sastre-Castillo, M. A. (2015). Personality traits versus work values: Comparing psychological theories on entrepreneurial intention. Journal of Business Research, 68(7), 1595-1598. https://doi.org/10.1016/j.jbusres.2015.02.001

Fragoso, R., Rocha-Junior, W., \& Xavier, A. (2019). Determinant factors of entrepreneurial intention among university students in Brazil and Portugal. Journal of Small Business and Entrepreneurship, 32(1), 33-57. https://doi.org/10.1080/08276331.2018.1551459

Gachanja, I. M. (2016). The influence of blended learning on entrepreneurial self-efficacy of university students. 5(03), 16-27.

Hair 2006. (n.d.).

Handayani, Y. C., \& Prajogo, W. (2020). Gender as a moderator in the relationship between entrepreneurial media expose, ATB, SN, perceived behavioral control, and entrepreneurial intention. International Journal of Innovation, Creativity and Change, 12(5), 226-237.

Handayati, P., Wulandari, D., Soetjipto, B. E., Wibowo, A., \& Narmaditya, B. S. (2020). Does entrepreneurship education promote vocational students' entrepreneurial mindset? Heliyon, 6(11), e05426. https://doi.org/10.1016/j.heliyon.2020.e05426

Hanson, J. D., Nothwehr, F., Yang, J. G., \& Romitti, P. (2015). Indirect and Direct Perceived Behavioral Control and the Role of Intention in the Context of Birth Control Behavior. Maternal and Child Health Journal, 19(7), 1535-1542. https://doi.org/10.1007/s10995-0141658-x

Haynie, J. M., Shepherd, D., Mosakowski, E., \& Earley, P. C. (2010). A situated metacognitive model of the entrepreneurial mindset. Journal of Business Venturing, 25(2), 217-229. https://doi.org/10.1016/j.jbusvent.2008.10.001

Hermawan, A. (2019). Peran perguruan tinggi islam dalam mewujudkan wirausahawan yang berkarakter. Jurnal Ilmu Ekonomi Syariah, 1(47), 69-82.

Hidayat, R. H., \& Pemasyarakatan, P. I. (2020). Langkah - Langkah Strategis Untuk Mencegah Pandemi Covid-19 Di Lembaga Pemasyarkatan. Jurnal Pendidikan Kes, 9(1), 43-55.

Hines, A. M., Lemon, K., \& Wyatt, P. (2004). Factors related to the disproportionate involvement of children of color in the child welfare system : a review and emerging themes. Children and Youth Services Review, 26(6), 507-527. https://doi.org/10.1016/j.childyouth.2004.01.007

Hsu, D. K., Burmeister-Lamp, K., Simmons, S. A., Foo, M. Der, Hong, M. C., \& Pipes, J. D. (2019). "I know I can, but I don't fit": Perceived fit, self-efficacy, and entrepreneurial intention. Journal of Business Venturing, 34(2), 311-326. https://doi.org/10.1016/j.jbusvent.2018.08.004

Ishoy, G. A. (2016). The theory of planned behavior and policing: how attitudes about behavior, subjective norms, and perceived behavioral control affect the discretionary enforcement decisions of police officers. Criminal Justice Studies, 29(4), 345-362. https://doi.org/10.1080/1478601X.2016.1225362

Jabeen, F., Faisal, M. N., \& Katsioloudes, M. I. (2017). Entrepreneurial mindset and the role of universities as strategic drivers of entrepreneurship: Evidence from the United Arab Emirates. Journal of Small Business and Enterprise Development, 24(1), 136-157. https://doi.org/10.1108/JSBED-07-2016-0117

Karimi, S., Biemans, H. J. A., Lans, T., Chizari, M., \& Mulder, M. (2016). The Impact of Entrepreneurship Education: A Study of Iranian Students' Entrepreneurial Intentions and Opportunity Identification. Journal of Small Business Management, 54(1), 187-209. https://doi.org/10.1111/jsbm.12137

Kim, C. N. T., Van, H. P., Van, H. T., \& Kim, T. P. (2020). The relationship between higher education 
and entrepreneurial Intention among Vietnamese students. Management Science Letters, 10(8), 1709-1718. https://doi.org/10.5267/j.msl.2020.1.009

Liñán, F., \& Chen, Y. W. (2009). Development and cross-cultural application of a specific instrument to measure entrepreneurial intentions. In Entrepreneurship: Theory and Practice (Vol. 33, Issue 3, pp. 593-617). https://doi.org/10.1111/j.1540-6520.2009.00318.x

Lindberg, E., Bohman, H., \& Hultén, P. (2017). Methods to enhance students' entrepreneurial mindset: a Swedish example. European Journal of Training and Development, 41(5), 450466. https://doi.org/10.1108/EJTD-10-2016-0078

Majale, M. (2008). Employment creation through participatory urban planning and slum upgrading: The case of Kitale, Kenya. Habitat International, 32(2), 270-282. https://doi.org/10.1016/j.habitatint.2007.08.005

Mathieu, C. (2015). Developing Attitudes Toward an Entrepreneurial Career Through Mentoring: The Mediating Role of Entrepreneurial Self-Efficacy. 1-14. https://doi.org/10.1177/0894845314568190

Mathisen, J. E., \& Arnulf, J. K. (2013). Competing mindsets in entrepreneurship: The cost of doubt. International Journal of Management Education, 11(3), 132-141. https://doi.org/10.1016/j.ijme.2013.03.003

McMullen, J. S., \& Kier, A. S. (2016). Trapped by the entrepreneurial mindset: Opportunity seeking and escalation of commitment in the Mount Everest disaster. Journal of Business Venturing, 31(6), 663-686. https://doi.org/10.1016/j.jbusvent.2016.09.003

Miao, C., Qian, S., \& Ma, D. (2017). The Relationship between Entrepreneurial Self-Efficacy and Firm Performance: A Meta-Analysis of Main and Moderator Effects. Journal of Small Business Management, 55(1), 87-107. https://doi.org/10.1111/jsbm.12240

Muhson, A., Wahyuni, D., \& Mulyani, E. (2012). Analisis Relevansi Lulusan Perguruan Tinggi. Jurnal Economia, 8(April), 42-52.

Murugesan, R., \& Jayavelu, R. (2017). The Influence of Big Five Personality Traits and Self-efficacy on Entrepreneurial Intention: The Role of Gender. Journal of Entrepreneurship and Innovation in Emerging Economies, 3(1), 41-61. https://doi.org/10.1177/2393957516684569

Naktiyok, A., Nur Karabey, C., \& Caglar Gulluce, A. (2010). Entrepreneurial self-efficacy and entrepreneurial Intention: The Turkish case. International Entrepreneurship and Management Journal, 6(4), 419-435. https://doi.org/10.1007/s11365-009-0123-6

Neneh, B. N. (2020). Entrepreneurial passion and entrepreneurial intention: the role of social support and entrepreneurial self-efficacy. Studies in Higher Education, 0(0), 1-17. https://doi.org/10.1080/03075079.2020.1770716

Ngoc Khuong, M., \& Huu An, N. (2016). The Factors Affecting Entrepreneurial Intention of the Students of Vietnam National University - A Mediation Analysis of Perception toward Entrepreneurship. Journal of Economics, Business and Management, 4(2), 104-111. https://doi.org/10.7763/joebm.2016.v4.375

Novita, I. N. (2015). Pengaruh Sikap Kewirausahaan, Norma Subyektif, dan Efikasi Diri terhadap Perilaku Berwirausaha Melalui Intensi Berwirausaha Mahasiswa. Jurnal Ekonomi Pendidikan Dan Kewirausahaan, https://journal.unesa.ac.id/index.php/jepk/article/view/741

Nowiński, W., \& Haddoud, M. Y. (2019). The role of inspiring role models in enhancing entrepreneurial intention. Journal of Business Research, 96(October 2018), 183-193. https://doi.org/10.1016/j.jbusres.2018.11.005

Nowiński, W., Haddoud, M. Y., Lančarič, D., Egerová, D., \& Czeglédi, C. (2019). The impact of entrepreneurship education, entrepreneurial self-efficacy and gender on entrepreneurial intentions of university students in the Visegrad countries. Studies in Higher Education, 
44(2), 361-379. https://doi.org/10.1080/03075079.2017.1365359

Ok, J. woo. (2020). 사회적 지지가 창업의도 및 창업행동에 미치는 영향에 관한 연구 : 창업자기효능감과 창업의도의 매개효과. Asia-Pacific Journal of Business Venturing and Entrepreneurship, 15(1), 151-165.

Osiri, John Kalu, Kungu, Kenneth, Dilbeck, M. (2019). Osiri-Kungu-Dilbeck-Predictors of entrepreneurial intentions and social entrepreneurial intentions-2019. Journal of Business Diversity, 19(1), 422-452.

Oyugi, J. L. (2015). The Mediating Effect of Self-Efficacy on the Relationship Between Entrepreneurship Education and Entrepreneurial Intentions of University Students. Journal of Entrepreneurship, Management and Innovation, 11(2), 31-56. https://doi.org/10.7341/20151122

Ozaralli, N., \& Rivenburgh, N. K. (2016). Entrepreneurial intention: antecedents to entrepreneurial behavior in the U.S.A. and Turkey. Journal of Global Entrepreneurship Research, 6(1). https://doi.org/10.1186/s40497-016-0047-x

Pakpahan, A. K. (2020). Covid-19 Dan Implikasi Bagi Usaha Mikro, Kecil, Dan Menengah. JIHI: Jurnal Ilmu Hubungan Internasional, 20(April), $2-6$. https://doi.org/https://doi.org/10.26593/jihi.v0i0.3870.59-64

Pfeifer, S., Šarlija, N., \& Zekić Sušac, M. (2016). Shaping the Entrepreneurial Mindset: Entrepreneurial Intentions of Business Students in Croatia. Journal of Small Business Management, 54(1), 102-117. https://doi.org/10.1111/jsbm.12133

Pihie, L., \& Arivayagan, K. (2016). Predictors of Entrepreneurial Mindset among University Students. International Journal of Humanities, Social Sciences and Education, 3(7), 1-9. https://doi.org/10.20431/2349-0381.0307001

Piperopoulos, P., \& Dimov, D. (2015). Burst Bubbles or Build Steam? Entrepreneurship Education, Entrepreneurial Self-Efficacy, and Entrepreneurial Intentions. Journal of Small Business Management, 53(4), 970-985. https://doi.org/10.1111/jsbm.12116

Pollack, J. M., Burnette, J. L., \& Hoyt, C. L. (2012). Self-Efficacy in the Face of Threats to Entrepreneurial Success: Mind-Sets Matter. Basic and Applied Social Psychology, 34(3), 287-294. https://doi.org/10.1080/01973533.2012.674452

Rajh, E., Budak, J., Ateljević, J., Davčev, L., Jovanov, T., \& Ognjenović, K. (2017). Entrepreneurial intentions in selected South-East European countries. Glasnik Srpskog Geografskog Društva, $592-610$.

Rankhumise, E. M. (2014). Entrepreneurial intentions among students: A case of Tshwane University of Technology, South Africa. Problems and Perspectives in Management, 12(2), $105-111$.

Ridley, D., Davis, B., \& Korovyakovskaya, I. (2017). Entrepreneurial Mindset and the University Curriculum. Journal of Higher Education Theory and Practice, 17(2), 79-100.

Ru, X., Wang, S., \& Yan, S. (2018). Exploring the effects of normative factors and perceived behavioral control on individual's energy-saving Intention: An empirical study in eastern China. Resources, Conservation and Recycling, 134(96), 91-99. https://doi.org/10.1016/j.resconrec.2018.03.001

Sahinidis, A., Stavroulakis, D., Kossieri, E., \& Varelas, S. (2019). Entrepreneurial Intention Determinants Among Female Students. The Influence of Role Models, Parents' Occupation and Perceived Behavioral Control on Forming the Desire to Become a Business Owner. Proceedings in Business and Economics, 173-178. https://doi.org/10.1007/978-3-030-124533_20

Sari, M. (2012). Usaha Mengatasi Problematika Pendidikan Sains Di Sekolah Dan Perguruan 
Tinggi. Al-Ta Lim, 19(1), 74. https://doi.org/10.15548/jt.v19i1.9

Schaefer, R., \& Minello, Í. F. (2019). Entrepreneurial education: entrepreneurial mindset and behavior in undergraduate students and professors. Revista de Negócios, 24(2), 61. https://doi.org/10.7867/1980-4431.2019v24n2p61-90

Scheepers, M. J. (2008). Entrepreneurial mindset of information and communication technology firms. SA Journal of Information Management, 10(4). https://doi.org/10.4102/sajim.v10i4.328

Shabbir, S. (2016). Mediating Role of Trust. International Business Management, 56(6), 915-929. https://doi.org/10.1002/hrm

Shi, Y., Yuan, T., Bell, R., \& Wang, J. (2020). Investigating the Relationship Between Creativity and Entrepreneurial Intention: The Moderating Role of Creativity in the Theory of Planned Behavior. Frontiers in Psychology, 11(June), 1-12. https://doi.org/10.3389/fpsyg.2020.01209

Shinnar, R. S., Hsu, D. K., \& Powell, B. C. (2014). Self-efficacy, entrepreneurial intentions, and gender: Assessing the impact of entrepreneurship education longitudinally. International Journal of Management Education, 12(3), 561-570. https://doi.org/10.1016/j.ijme.2014.09.005

Sirhan Fikri, Wahyu Wiyani, A. S. (2016). Pengaruh kualitas pelayanan terhadap kepuasan dan loyalitas mahasiswa. Jurnal Bisnis Dan Manajemen, 3(1), 120-134.

Soleh, A. (2017). Masalah ketenagakerjaan dan pengangguran di indonesia. Jurnal Ilmiah Cano Ekonomos, 6(2), 83-92.

Solesvik, M. Z., Westhead, P., Matlay, H., \& Parsyak, V. N. (2013). Entrepreneurial assets and mindsets: Benefit from university entrepreneurship education investment. Education + Training, 55, 748-762. https://doi.org/10.1108/ET-06-2013-0075

Song, C. W., \& Park, J. Y. (2020). How Entrepreneurial Mindset of Office Workers Affects Entrepreneurial Intention: Roles of Social Capital and State-action Orientation. Journal of Business Venturing and Entrepreneurship, 15(3), 73-88.

Syawfi, I. (2020). Implikasi Pandemi COVID-19 terhadap Hubungan Internasional : Menuju dunia Paska-Liberal. Jurnal Ilmiah Hubungan Internasional -Pacis, 2019(April). http://103.36.68.33/index.php/JurnalIlmiahHubunganInternasiona/article/view/3864/2909

Telaumbanua, D. (2020). Urgensi Pembentukan Aturan Terkait Pencegahan Covid-19 di Indonesia. QALAMUNA: Jurnal Pendidikan, Sosial, Dan Agama, 12(01), 59-70. https://doi.org/10.37680/qalamuna.v12i01.290

Travis, J., \& Freeman, E. (2017). Predicting entrepreneurial intentions: Incremental validity of proactive personality and entrepreneurial Self-Efficacy as a moderator. Journal of Entrepreneurship Education, 20(1), 45-57.

Tsai, K. H., Chang, H. C., \& Peng, C. Y. (2016). Refining the linkage between perceived capability and entrepreneurial intention: roles of perceived opportunity, fear of failure, and gender. International Entrepreneurship and Management Journal, 12(4), 1127-1145. https://doi.org/10.1007/s11365-016-0383-x

TUU, H. H. (2015). Attitude, Social Norms, Perceived Behavioral Control, Past Behavior, and Habit in Explaining Intention to Consume Fish in Vietnam. Journal of Economics Development, 22(3), 102-122. https://doi.org/10.24311/jed/2015.22.3.06

Vamvaka, V., Stoforos, C., Palaskas, T., \& Botsaris, C. (2020). Attitude toward entrepreneurship, perceived behavioral control, and entrepreneurial intention: dimensionality, structural relationships, and gender differences. Journal of Innovation and Entrepreneurship, 9(1). https://doi.org/10.1186/s13731-020-0112-0

Walgito (2005:216-217) dalam Eny Endah Pujiastuti, 2013:5), Robledo, J. L. R., Arán, M. V., MartinSanchez, V., Molina, M. Á. R., Authors, F., E-commerce, K. D. A. N. P., Peningkatan, P., Berwirausaha, M., Soon, F., Thiam, W., Husna, A., Bidin, Z., Sharif, Z., Ahmad, A., Franche, 
Æ., Rene, Æ., Carr, J. C., Sequeira, J. M., ... Johari, J. (2015). Pengaruh Kepribadian Dan Lingkungan Terhadap. Jurnal Inovasi Dan Kewirausahaan, 2(1), 92-117. https://doi.org/10.3926/ic.557

Wardana, L. W., Narmaditya, B. S., Wibowo, A., Mahendra, A. M., Wibowo, N. A., Harwida, G., \& Rohman, A. N. (2020). The impact of entrepreneurship education and students' entrepreneurial mindset: the mediating role of attitude and self-efficacy. Heliyon, 6(9), e04922. https://doi.org/10.1016/j.heliyon.2020.e04922

WHO. (2020). Coronavirus Disease 2019 (COVID-19) Situation Reports. April 1 2020. WHO Situation Report, 2019(72), 1-19. https://www.who.int/docs/defaultsource/coronaviruse/situation-reports/20200324-sitrep-64-covid-

19.pdf?sfvrsn=703b2c40_2\%0Ahttps://www.who.int/docs/default-

source/coronaviruse/situation-reports/20200401-sitrep-72-covid-19.pdf?sfvrsn=3dd8971b_2

Wong, P. K., Ho, Y. P., \& Singh, A. (2007). Towards an "Entrepreneurial University" Model to Support Knowledge-Based Economic Development: The Case of the National University of Singapore. World Development, 35(6), 941-958. https://doi.org/10.1016/j.worlddev.2006.05.007

Wongpreedee, K., Kiratisin, A., \& Virutamasen, P. (2015). Entrepreneurial Mindsets for Innovative Brand Development: Case Studies in Jewellery Education. Procedia - Social and Behavioral Sciences, 195, 2236-2241. https://doi.org/10.1016/j.sbspro.2015.06.308

Yang, J. (2013). The theory of planned behavior and prediction of entrepreneurial Intention among Chinese undergraduates. Social Behavior and Personality, 41(3), 367-376. https://doi.org/10.2224/sbp.2013.41.3.367

Yusof, W. N. H. S. W., Zainol, F. A., \& Daud, W. N. W. (2018). Entrepreneurial Intention Revisited: The Role Of Entrepreneurial Self-Efficacy. International Journal of Academic Research in Business and Social Sciences, 8(12), 1223-1235. https://doi.org/10.6007/ijarbss/v8-i12/5209

Zampetakis, L. A., Gotsi, M., Andriopoulos, C., \& Moustakis, V. (2011). Creativity and Entrepreneurial Intention in Young People. The International Journal of Entrepreneurship and Innovation, 12(3), 189-199. https://doi.org/10.5367/ijei.2011.0037 